\title{
Commercial Banks Profitability Position: The Case of Tanzania
}

\author{
Xuezhi Qin ${ }^{1} \&$ Dickson Pastory ${ }^{1}$ \\ ${ }^{1}$ School of Business Management, Dalian University of Technology, Dalian, China \\ Correspondence: Dickson Pastory, School of Business Management, Dalian University of Technology, Dalian \\ 116024, China. Tel: 86-188-4268-6991. E-mail: passtory1@yahoo.co.uk
}

Received: May 24, 2012

doi:10.5539/ijbm.v7n13p136
Accepted: June 5, 2012

Published: July 1, 2012

URL: http://dx.doi.org/10.5539/ijbm.v7n13p136

\begin{abstract}
The study examines commercial banks profitability in Tanzania for the period of ten years (2000-2009).The study used National Microfinance Bank (NMB), National Bank of Commerce (NBC) and CRDB as the case study. The study employed the profitability measures of commercial banks, and the evidence of performance in terms of profitability was established based on return on average asset, net interest income to average bearing assets and non-interest expenses to average assets. The paper utilized panel secondary data from National bank of commerce, CRDB and National Microfinance bank in Tanzania for the period of ten years, and the hypothesis was tested to know whether there is a significant difference in terms of profitability by using ANOVA test. Finally the regression model was run to see the effects of capital adequacy, liquidity and asset quality on the profitability of commercial banks. The findings revealed that there is no significant difference on profitability among the commercial banks, in the context of regression model it has been noted that liquidity and asset quality has positive impact in profitability with exception to the level of nonperforming loans which has a negative influence on profitability. Also capital adequacy has shown negative impact on profitability. The study confirmed the profitability of commercial banks to stable and meeting the regulatory requirement of the Bank of Tanzania (BOT).
\end{abstract}

Keywords: profitability measures, financial statements analysis, Tanzania

\section{Introduction}

Commercial banks in Tanzania have gone into significant changes after the liberization of the banking system. The reforms removed barriers to entry of commercial banks and supported the improvement of institutional framework and more efficiently the performance of commercial banks, with this it has affected the profitability of commercial banks and increased banking competition. Profitability of commercial banks is pro foundation for product innovation, diversification and efficiency of the commercial banks (Hempell, 2002). The stability of commercial banks as whole in the economy depends on profitability level. More profitability level has tendency to absorb risks and shocks that commercial banks can face. Moreover profitability is the perquisite condition for the efficiency of commercial banks. Empirical evidence from detriguache (1999) has showed that the soundness of commercial banks performance depends on profitability. Francis (2006) has indicated that markets reforms in the sub-Saharan Africa has worsen the profitability of commercial banks due to high level of non-performing loans. This is contradictory to the early study of chijoriga (1997) who indicated that market liberiztion is essential for high level profitability of commercial banks. Profitability of commercial banks is important for the efficiency of commercial banks. According to the bank of Tanzania (2010), the commercial banks profitability has improved to the greatest extent and most of them are above the regulatory requirements, the greatest profitability earned by these commercial banks indicates that the internal factors has played a great role toward this profitability, Therefore to fill the above void the profitability test for giant's commercial banks in terms of market share was examined to confirm the profitability level of commercial banks. Meanwhile regression model was run in order to test profitability relationship with liquidity, asset quality and capital adequacy.

\section{Indicator of Profitability Measure}

Profitability in commercial banks is determined by the ability of the banks to retain capital, absorb loan losses, support future growth of assets and provide return to investors. The largest source of income to the bank is interest income from lending activity less interest paid on deposits and debt .In this study profitability was 
measured by three ratios which are net interest margin, return on assets and return on equity. Bank of Tanzania (2007) has set some standard measures of profitability such as: Return on equity directly reflects corporate competitiveness strength and sustainable growth. It is an important indicator in the attractiveness of the equity in the eyes of investors. Return on Asset effectively reflects corporate profitability which can be used to evaluate the performance of management in the utilization of the assets. It is calculated by dividing net income by average value of total assets over the same period. This intend to measure bank efficiency using its asset. Net interest income to average interest bearing assets; this ratio is calculated by taking total interest income less total interest expenses divided by average of the bearing assets. This intend to measure bank efficiency in using its interest bearing assets.

In order to rate the profitability level of commercial banks, the bank of Tanzania use the rating approach which is in line with the Basel framework of banking and risk supervision. They are being accorded and evaluated on specific performance, in our case being profitability. The rating is based on the scale of 1 to 5 in ascending order of supervision requirements. Rating one indicates the strongest possible profit level that means the profitability level is above average, Rating two indicates satisfactory and reflects performance in terms of profitability that is average for the soundness operation of the banks, Rating three represents fair profit that is flawed to some degree, it is neither satisfactory nor unsatisfactory but it is characterized by performance below average quality, Rating 4 indicates marginal profit and the profit is below average if not changed such performance might involve into weakness or condition that could threatens the viability of the bank and finally unsatisfactory profit is the lowest profit that indicates there is a need to take remedial attention for future sustainability of the bank.

The financial ratios of individual institutions generate a warning system if ratio exceeds a predetermined critical levels or lies within a set of internal or it exceeds the boundaries of the set standards. The warning system helps to understand the stability of the commercial banks and trend of commercial banks in general.

Table 1. The following are standards that account for the profitability of commercial banks

\begin{tabular}{llll}
\hline Ratings & Return on average assets & $\begin{array}{l}\text { Net interest income to } \\
\text { average Earning Assets } \\
\text { Net interest income to } \\
\text { average earning assets }\end{array}$ & $\begin{array}{l}\text { Non-interest expenses to } \\
\text { average assets. } \\
\text { Non-interest expenses } \\
\text { to average assets }\end{array}$ \\
\hline 1 & Above 3\% & Above 5\% & Below $4 \%$ \\
2 & $2 \%-3 \%$ & $3 \%-5 \%$ & $4 \%-8 \%$ \\
3 & $1 \%-2 \%$ & $1 \%-3 \%$ & $8 \%-12 \%$ \\
4 & $0 \%-1 \%$ & $0 \%-1 \%$ & $12 \%-16 \%$ \\
5 & Below $0 \%$ & Below $0 \%$ & Above $16 \%$ \\
\hline
\end{tabular}

Source: BOT, 2010

\subsection{Empirical Review}

Due to the great importance of profitability for good functioning of the banking system, there are several authors that have devoted their time in this area, see

Sufian (2009), studied the determinant of commercial banks profitability, the paper indicated that both the internal determinant and external determinant are crucial in the profitability of commercial banks. Nazir (2010), analyzed the financial performance in India, his study indicated that capital adequacy, liquidity, asset quality and management are crucial in influencing the financial performance of the commercial banks. Naceur (2003) investigated the determinant of commercial banks in Tunisia; the study revealed that the financial structure, banks characteristics and macroeconomic variables have potentials effect on the profitability of the commercial banks. Molyneux and Thornton (1992) investigated the profitability of 18 European countries; their findings revealed that interest rates, government policy and bank regulation has potential impact on profitability of the commercial banks, also Demerguc-kunt and Huizigha (1999) in their study on determinant of commercial banks profitability revealed the same story. However other studies such as miller and Noulas (1996) indicated that the profitability of commercial banks is being determined by the efficiency of the commercial banks itself. Staikous and Steliaros (1999) showed that the profitability of commercial banks has been influenced by the inflation rate, proprietary regime and core capital. Furthermore khrawish (2011) investigated the determinant of commercial 
banks in Jordan, bank size and total liabilities to total asset are found to have negative impact on the profitability while GDP and inflation are found to have a negative impact on the financial performance of commercial banks.

\section{Methodology of the Study}

The study employed panel secondary data from the three commercial banks for the period of 2000-2009. Traditional ratio analysis was employed to find the profitability measures of commercial banks and was run through excel to find the ratios. Descriptive analysis was employed to explain the profitability of commercial banks for the entire period as it is best suited in the comparative study (Kothari, 1990). The ratios were run through SPSS to find if there is a significant difference in terms of profitability of the commercial banks understudy. Meanwhile regression model was run to see the relationship of the profitability as measured by return on asset and other independent variables such as capital adequacy, liquidity and asset quality.

The regression equation is here under

$$
y=(x, z, u, e) \ldots \ldots \ldots \ldots \ldots . . i
$$

Where $\mathrm{y}=$ profitability as measured by return on asset, $\mathrm{x}=$ capital adequacy position of commercial bank $\mathrm{z}=$ liquidity position of the commercial bank, $\mathrm{u}=$ asset quality of the commercial banks and $\mathrm{e}$ is a stochastic error

$$
\begin{gathered}
y=\alpha+\sum x_{n}+\sum z_{n}+\sum u_{n}+e \ldots \ldots \ldots . . i i \\
y=\alpha+\beta_{1} x_{1}+\beta_{2} x_{2}+\lambda_{1} z_{1}+\lambda_{2} z_{2}+\lambda_{3} z_{3}+\kappa_{1} u_{1}+k_{2} u_{2}+k_{3} u_{3}+e \ldots \ldots . . i i i
\end{gathered}
$$

Where $\beta \quad$ is the coefficient of capital adequacy determined by core capital to off balance sheet exposure, and core leverage to total assets, $\lambda$ is the coefficient of liquidity measured by core deposit to total funding, liquid asset to demand liabilities and gross loans to total deposit and finally $k$ is the asset quality coefficient measured by non-performing loans to gross loans, large exposure to core capital and non-performing loans net of provision to core capital.

According to Basel II, capital adequacy is necessary and pre-condition for the survival of the commercial banks because capital tends to absorbs losses in the period of bank failure but there is a contradictory argument whether capital results into higher profit or low profit. Higher capital may lead to the lower profitability because the investors are rigid to make great investments to avoid potential losses in future while on the other hand higher capital can result into higher profitability as commercial banks can avoid the payments of fixed interest expenses but dividends payments is optional can be paid or not paid. The non-paid dividend can be reinvesting back in the form of retained earnings and results into great profit (Berger, 1995).Keeley and Furay (1990) state that capital acts as a buffer against banks failure and reduce the likelihood of bank bankruptcy. Asset quality and liquidity are expected to have positive sign on profitability; Chijoriga (1997) noted that poor asset quality and low level of liquidity resulted into banking failure. Asset quality in terms of credit risk results into the non-repayments of loans hence lower interest revenue but better asset quality in terms of the lower percentage of non-performing loans results into higher profitability (Brock and suarez, 2000). The commercial banks need to strike balance between higher level of liquidity and lower level of liquidity, as higher level of liquidity is not desirable can results into low level of profitability since very little amount of cash is issued as loans. Meanwhile low level of liquidity meaning that the banks have very little cash to suffice hence low profitability. Althanasoghou (2006) indicated that liquidity is the source of the bank's profitability; it can accommodate the decrease in liabilities and finance the increase in banking assets. Bank of Tanzania (2010) has confirmed the commercial banks to be operated in higher level of liquidity which is above the regulatory requirements.

\section{Findings}

The paper objective was meant to analyze the earning position of commercial banks, to achieve this three ratios were computed and analyzed using return on asset, Net interest income to average earning assets and non-interest expenses to average assets as indicated in Tables 2, 3 and 4 . The higher the value is the better except for non-interest expenses to average assets which is supposed to be below $4 \%$ as the best bank performer (BOT, 2007) 
Table 2. Comparative net interest income to average interest bearing asset analysis

\begin{tabular}{llll}
\hline Year & CRDB & NMB & NBC \\
\hline 2000 & $12.61 \%$ & $7.02 \%$ & $5.88 \%$ \\
2001 & $9.63 \%$ & $5.32 \%$ & $6.27 \%$ \\
2002 & $5.38 \%$ & $4.27 \%$ & $7.05 \%$ \\
2003 & $6.41 \%$ & $5.39 \%$ & $6.23 \%$ \\
2004 & $7.28 \%$ & $8.75 \%$ & $7.77 \%$ \\
2005 & $6.92 \%$ & $10.03 \%$ & $9.16 \%$ \\
2006 & $7.86 \%$ & $12.27 \%$ & $9.72 \%$ \\
2007 & $8.95 \%$ & $13.10 \%$ & $10.30 \%$ \\
2008 & $9.02 \%$ & $11.98 \%$ & $9.67 \%$ \\
2009 & $8.45 \%$ & $10.88 \%$ & $10.29 \%$ \\
\hline
\end{tabular}

Table 3. Comparative non-interest expenses to average asset analysis

\begin{tabular}{llll}
\hline Year & CRDB & NMB & NBC \\
\hline 2000 & $4.28 \%$ & $7.31 \%$ & $2.59 \%$ \\
2001 & $6.83 \%$ & $7.50 \%$ & $5.44 \%$ \\
2002 & $6.98 \%$ & $6.13 \%$ & $6.25 \%$ \\
2003 & $5.41 \%$ & $5.87 \%$ & $5.45 \%$ \\
2004 & $5.46 \%$ & $6.02 \%$ & $6.02 \%$ \\
2005 & $4.94 \%$ & $5.92 \%$ & $5.49 \%$ \\
2006 & $4.80 \%$ & $7.18 \%$ & $4.72 \%$ \\
2007 & $5.43 \%$ & $7.61 \%$ & $5.33 \%$ \\
2008 & $5.53 \%$ & $6.59 \%$ & $6.39 \%$ \\
2009 & $5.23 \%$ & $6.17 \%$ & $6.06 \%$ \\
\hline
\end{tabular}

Table 4. Comparative return on average asset analysis

\begin{tabular}{llll}
\hline Year & CRDB & NMB & NBC \\
\hline 2000 & $0.83 \%$ & $1.46 \%$ & $0.12 \%$ \\
2001 & $1.30 \%$ & $2.48 \%$ & $2.85 \%$ \\
2002 & $0.30 \%$ & $2.66 \%$ & $2.9 \%$ \\
2003 & $2.17 \%$ & $2.53 \%$ & $3.31 \%$ \\
2004 & $3.31 \%$ & $5.32 \%$ & $3.27 \%$ \\
2005 & $3.96 \%$ & $5.78 \%$ & $4.62 \%$ \\
2006 & $4.64 \%$ & $6.28 \%$ & $5.03 \%$ \\
2007 & $5.07 \%$ & $5.71 \%$ & $5.27 \%$ \\
2008 & $4.63 \%$ & $4.86 \%$ & $5.26 \%$ \\
2009 & $3.64 \%$ & $4.38 \%$ & $4.75 \%$ \\
\hline
\end{tabular}

\section{Source: field data, 2010}

Table 4, shows the level of earning as measured by the return on average asset. In 2000, NMB was having higher return on asset followed by CRDB and then NBC. In 2001 return on asset increased from its former level and it was higher for NBC followed by NMB and then CRDB, in 2002 the return on asset decreased from its former level and NBC maintained the lead followed by NMB and then CRDB. In 2003 to 2005 the return on asset was 
increasing and it was higher for NMB followed by NBC and then CRDB. For year 2006 it was higher for NMB, followed by NBC and the last was CRDB. The return on asset trend remained the same in the year 2007 but it decreased for NMB from the former level, while that of CRDB and NBC increased gradually. However, in year 2009 there was a falling trend from all three commercial banks and NBC was having higher return on average asset compared to the counter parts. In 2000 CRDB and NBC showed earning in terms of return on asset that are deficient, earning was insufficient to support operations and maintain appropriate capital and allowance levels, the bank was characterized by erratic fluctuations in net income or interest margins. The institutions may be characterized by development of significant trends, nominal or unstable earnings, intermittent loses or a substantive drop in earnings from the previous years and NMB during the same year was having earnings that needed improvement. Earning was not fully supporting operations and provide for accumulations of capital and allowance levels in relation to institution overall condition, growth and other factor affecting quality, quantity and trend of earnings. In 2001 CRDB indicated earnings that needed improvement and earning was not fully supporting the operations while that of NBC and NMB indicated earning that was satisfactory to support the operations. In 2002 CRDB showed the earning that is deficient and earning was insufficient to support the operations while NBC and NMB showed the earnings that was satisfactory to support operations. In 2003 both commercial banks showed earnings that were satisfactory to support operation. In 2004 to $2005 \mathrm{NMB}$, NBC and CRDB indicated strong earnings. In the whole period of 2006 to 2009 the commercial banks under study NMB, CRDB and NBC showed strong level of earnings in terms of return on asset because they were far from the regulatory requirement, earnings are more than sufficient to support operations and maintain adequate capital and allowance levels after consideration is given to asset quality, growth and other factors affecting the quality, quantity and trend of earnings.

From Table 2, shows the level of earning as measured by the net interest income to average earning assets in 2000 it was higher for CRDB followed by NMB and then NBC. In 2001 CRDB maintained the lead but there was a declining trend from its former level followed by NMB and then NBC, in 2002 earning was higher for NBC followed by CRDB and then NMB, NMB and CRDB depicted a falling trend while NBC there was gradual rising trend. In 2003 it was higher for CRDB followed by NBC and then NMB. In 2004 to 2005 NMB was having higher earning followed by NBC and then CRDB. In year 2006 it was higher for NMB, followed by NBC and the last was CRDB. The net income to average bearing assets trend was remained the same in the year 2007 and increased gradually. However, in year 2008 there was a falling trend from all three commercial banks and NMB was having higher net interest income to average earning assets compared to the counter parts. The facts are the same in year 2009 but NBC performance picked up compared to CRDB and NMB who noticed a falling trend. In the whole period of the analysis the commercial banks under study NMB , CRDB and NBC showed the level of strong earnings, earnings are more than sufficient to support operations and maintain adequate capital and allowance levels after consideration is given to asset quality, growth and other factors affecting the quality, quantity and trend of earnings.

From Table 3, shows the level of earning as measured by non-interest expenses to average asset it was higher for NMB, followed by CRDB and then NBC in 2000 and 2001,in 2002 non-interest expense to average asset was higher for CRDB followed NBC and then NMB. In 2003 to 2005 NMB was having higher non-interest expense to average asset, followed by NBC and then CRDB. In 2006 it was higher for NMB, followed by CRDB and the last was NBC. The trend was remained the same in the year 2007 and increased gradually. However in year 2008 there was a falling trend to NMB. However, other banks its performance ratio picked up .The facts are the same in year 2009 noticed a falling trend to all three commercial banks. In this category the lower the ratio the better performance. For the whole period understudy the commercial banks indicated the satisfactory earning level in terms of non-interest expenses to average assets; earning are sufficient to support operations and maintain adequate capital and allowance levels after consideration is given to asset quality, growth, and other factors affecting quality, quantity and trend of earnings.

\subsection{Overall Description of Earning Performance of the Banks}

With analysis of table 4.1, 4.2 and 4.3, in 2000 the three commercial banks showed stable condition in terms of earnings condition. In $2001 \mathrm{NMB}$ and CRDB showed stable financial condition and strong performance while NBC showed a very strong condition and at that time no supervisory requirement required. In 2002, NBC showed a very strong financial stability in terms of earnings, followed by NMB which showed sound financial stability while CRDB showed moderate financial condition as it revealed weakness in earnings and hence supervisory requirement was needed. In year 2003 to 2009 all three commercial banks showed sound and stable financial performance in terms of earning level. In this case with help of the benchmark pointed out above these commercial banks give no cause for management supervision and control. The facts are the same in 2007, 2008 
and 2009, where the banks remained to be stable and sound in financial performance.

\subsection{Hypothesis Testing}

There is no significant difference in earning positions of commercial banks in Tanzania.

There is significant difference in earning positions among commercial banks in Tanzania. Results of the test significance at $95 \%$ confidence interval (that is, 0.05 level of significance) indicated the following: First, in the aspect of return on assets, the mean calculated for all companies was not very much different between NMB, CRDB and NBC. The test of one-way ANOVA under this aspect indicated no significant difference between the commercial banks profitability positions since the F statistic was 1.230 , while the F table was 5.14. This justified the null hypothesis that there are no significant differences in earning positions of commercial banks Secondly, results net interest income to average interest bearing asset do not differ very much from all companies. The test of one-way ANOVA produced an F statistic of 0.246 and the F table of 5.14. This resulted in the rejection of the alternative hypothesis that there are significant differences in the earning positions of the commercial banks. Therefore, the Null hypothesis is accepted and the alternative hypothesis is rejected. Thirdly, results for mean are not much different in case of non-interest expenses to average assets for each company. The mean of earnings for CRDB is 5.4890, NMB is 6.6300 and NBC is 5.3740.The test of one-way ANOVA at 0.05 significance level under this aspect indicated a significant difference between the commercial banks liquidity positions since the $\mathrm{F}$ statistic was 6.018 , while the F table was 5.14. With such results, the null hypothesis was rejected and the alternative hypothesis was accepted

\subsection{The Findings Results from the Regression Model}

It has indicated that the adjusted R square is $73.5 \%$, which means the profitability level as measured by liquidity, capital adequacy and asset quality is explained in that percentage, however the $\mathrm{R}$ square is $81.8 \%$ meaning that the independent variables explain well the dependent variable which is return on asset on our course. However the model depicted that 2814 million loss in the absence of the independent variables, thus the capital adequacy, liquidity and asset quality are more crucial in the profitability of commercial banks, in absence of them the commercial banks will always incur loses. The coefficient s of core capital to off balance sheet and core capital to total assets are negative. This proves that the capital structure has negative determinant on profitability, the assets quality coefficient has shown positive value in coefficients except the ratio of non-performing loans which has shown negative coefficients which showed that it tends to decrease the profit. Finally all ratios of liquidity have shown positive coefficient which show they contribute much on overall profitability of commercial banks (see appendix 1)

\section{Conclusion}

The banking industry in Tanzania provides an insight into the development of commercial banks industry. This was activated by the changed policies from state owned (centralized) economy to more liberalized economy under the banner of liberalization. Moreover, the Bank of Tanzania Act of 1991 made a profound impact in commercial banks investment that cropped up more than forty three banking institutions. This study intended to assess the profitability performance of the commercial banks industry with special reference of CRDB, NBC and NMB. The analysis was for ten years. Performance was evaluated in terms of net interest income to total asset, return on asset and non-performing loans to gross loans. Statistical analysis was done using one way Analysis of Variance (ANOVA) whereby the hypothesis was tested. The hypothesis tested was on the significant differences in profitability positions for commercial banks. On this hypothesis it was revealed that there was no significant difference on the profitability position. Generally the profitability of commercial remains to be sound in all three commercial banks and this has been activated due to the dominance of market share in the industry. Moreover regression model depicts special influence of capital adequacy, liquidity and asset quality on profitability level.

\section{Acknowledgment}

The research is supported by the Ph. D. Programs Foundation of Ministry of Education of China (20090041110009), National Science Foundation of Ministry of China (71171032), and the central university special funds for basic research business expenses (DUT11RW202, DUT10ZD107).

\section{References}

Athanasoglou, P.P., Delis, M.D., \& Staikouras, C.K. (2006). The Determinants of Bank profitability in the South Eastern European Region. Bank of Greece Working Paper.

Bank of Tanzania. (2007). Risk based Financial institution Framework.

Banking \& financial institution Act (BFIA). (1991). United Republic of Tanzania. 
Ben Naceur, S. (2003). The determinants of the Tunisian banking industry profitability: panel evidence. Paper presented at the Economic Research Forum (ERF) 10th Annual Conference, Marrakesh-Morocco, 16-18 December.

Berger, A. (1995). The relationship between capital and Earning in Banking. Journal of money, credit and Banking, 27, 404-431. http://dx.doi.org/10.2307/2077876

Chijoriga, M.M. (1997). An application of credit score and financial distress prediction models to commercial banks lending: The case of Tanzania. phd thesis, wu wein university.

Demerguç-Kunt A., \& Huizinga H. (1999). Determinants of commercial bank interest margins and profitability: Some international evidence. World Bank Economic Review, 13, 379-408. http://dx.doi.org/10.1093/wber/13.2.379

Demirgüç-Kunt, A., \& Detragiache, E. (1999). Monitoring banking sector fragility: a multivariate logit approach. IMF Working Paper, No. 106.

Francis E. (2007). Determinant of commercial banks profitability in sub Saharan Africa. Retrieved from http://daadpartnership.htwberlin.de/fileadmin/Workshops/2011_Uganda/Abstracts_and_Papers/Munyambo nera_Commercial_banks_Profitability_in_SSA.pdf. Visited on $10^{\text {th }}$ April 2012

Hempell H. (2002). Testing competition among the German banks. Discussion paper 04/02 of the deutsche bundesbank.

Keeley M. C., \& Furlong F. T. (1990). Re-examination of Mean Variance Analysis of Bank Capital Regulations. Journal of Banking and Finance, 14, 69-84. http://dx.doi.org/10.1016/0378-4266(90)90036-2

Khrawish H. (2011). Determinant of commercial banks performance in Jordan. International journal of finance and economics, 81 .

Miller S., \& Noulas A. (1996). The Technical Efficiency of Large Banks Production. Journal of Banking \& Finance, 20(3), 495-509. http://dx.doi.org/10.1016/0378-4266(95)00017-8

Molyneux P., \& Thornton J. (1992). The determinants of European bank profitability. Journal of Banking and Finance, 16, 1173-1178. http://dx.doi.org/10.1016/0378-4266(92)90065-8

Noulas, A. (1999). Profitability and Efficiency of the Greek Banks (1993-1998). Journal of the Banking Association of Greece, 19(20), 53-60.

Staikouras C., \& Steliaros M. (1999). Determinants Factors of Profitability of the Greek Banking System. Journal of the Banking Association of Greece, 19(20), 61-66.

Sufian, F., \& Chong, R. R. (2008). Determinants of Bank Profitability in a Developing Economy: Empirical Evidence from Philippines. Asian Academy of Management Journal of Accounting and Finance, 4(2) 91-112. Retrieved from http:// www.usm.my/journal/aamjaf/vol\%204-2-2008/4-2-5

\section{Appendix I}

\begin{tabular}{lllllll}
\hline Model & & Sum of Squares & df & Mean Square & F & Sig. \\
\hline \multirow{2}{*}{ Regression } & $5.072 \mathrm{E} 7$ & 9 & 5635829.005 & 9.957 & $.000^{\mathrm{a}}$ \\
Residual & $1.132 \mathrm{E} 7$ & 20 & 566039.240 & & \\
Total & $6.204 \mathrm{E} 7$ & 29 & & \\
\hline \multicolumn{7}{c}{ Model summary } \\
Model & $\mathrm{R}$ & $\mathrm{R}$ & square & Adjusted R square & Std error \\
\hline 1 & $.904^{\mathrm{a}}$ & .818 & .735 & $00: 12: 32.356$ \\
\hline
\end{tabular}

\begin{tabular}{|c|c|c|c|c|}
\hline \multirow{2}{*}{\multicolumn{2}{|c|}{ Model }} & & \multicolumn{2}{|c|}{ Unstandardized Coefficients } \\
\hline & & & $\mathrm{B}$ & Std. Error \\
\hline \multirow[t]{2}{*}{1} & (Constant) & & -2814.529 & 1576.245 \\
\hline & Capital to Rwa & $\beta_{1}$ & -.032 & .038 \\
\hline
\end{tabular}




\begin{tabular}{lcll}
\hline Core capital to asset & $\beta_{2}$ & -.201 & .110 \\
NPL to gross loan & $\lambda_{1}$ & -.043 & .139 \\
lextocorec & $\lambda_{2}$ & .001 & .002 \\
npl to ccp & $\lambda_{3}$ & .012 & .015 \\
code to fund & $\mathrm{Z}_{1}$ & .081 & .029 \\
liq to delb & $\mathrm{Z}_{2}$ & -.006 & .022 \\
grosl to td & $\mathrm{Z}_{3}$ & .020 & .021 \\
\hline
\end{tabular}

Where lextocorec means large exposure to core capital, npl to ccp means non performing loans to core capital, code means core deposits to total funding, lid to delb means liquid assets to demand liabilities and grosl to td means gross loans to total deposit.

\section{Appendix II}

Ho: There was no significant difference in earning positions among commercial banks in Tanzania $\mathrm{H}_{i}$ There was a significant difference in earning position among commercial banks in Tanzania ANOVA Return on asset

\begin{tabular}{llclll}
\hline & $\begin{array}{l}\text { Sum } \\
\text { Squares }\end{array}$ & of Df & $\begin{array}{l}\text { Mean } \\
\text { Square }\end{array}$ & F & Sig. \\
\hline $\begin{array}{l}\text { Between } \\
\text { Groups }\end{array}$ & 6.938 & 2 & 3.469 & 1.230 & .308 \\
Within & 76.175 & 27 & 2.821 & & \\
Groups & & & & & \\
Total & 83.113 & 29 & & & \\
\hline
\end{tabular}

Mean and standard deviation table of return on asset

\begin{tabular}{llll}
\hline Banks & Mean & N & Standard deviation \\
\hline CRDB & 2.9850 & 10 & 1.72028 \\
NMB & 4.1460 & 10 & 1.71343 \\
NBC & 3.7380 & 10 & 1.60270 \\
Total & 3.6230 & 30 & 1.69291 \\
\hline
\end{tabular}

ANOVA

Return on asset

\begin{tabular}{llclll}
\hline & $\begin{array}{l}\text { Sum } \\
\text { Squares }\end{array}$ & ofDf & $\begin{array}{l}\text { Mean } \\
\text { Square }\end{array}$ & F & Sig. \\
\hline $\begin{array}{l}\text { Between } \\
\text { Groups }\end{array}$ & 6.938 & 2 & 3.469 & 1.230 & .308 \\
Within & 76.175 & 27 & 2.821 & & \\
Groups & & & & & \\
Total & 83.113 & 29 & & & \\
\hline
\end{tabular}


Mean and standard deviation table of return on asset

\begin{tabular}{llll}
\hline Banks & Mean & $\mathrm{N}$ & Standard deviation \\
\hline CRDB & 2.9850 & 10 & 1.72028 \\
NMB & 4.1460 & 10 & 1.71343 \\
NBC & 3.7380 & 10 & 1.60270 \\
Total & 3.6230 & 30 & 1.69291 \\
\hline
\end{tabular}

ANOVA

Net interest income to average interest bearing asset

\begin{tabular}{llllll}
\hline & $\begin{array}{l}\text { Sum } \\
\text { Squares }\end{array}$ & ofDf & $\begin{array}{l}\text { Mean } \\
\text { Square }\end{array}$ & F & Sig. \\
\hline $\begin{array}{l}\text { Between } \\
\text { Groups }\end{array}$ & 2.892 & 2 & 1.446 & .246 & .784 \\
Within & 158.987 & 27 & 5.888 & & \\
Groups & & & & & \\
Total & 161.879 & 29 & & & \\
\hline
\end{tabular}

Mean and standard deviation of net interest income to average interest bearing asset

ANOVA

\begin{tabular}{llll}
\hline Banks & Mean & $\mathrm{N}$ & Standard deviation \\
\hline CRDB & 8.2510 & 10 & 2.01443 \\
NMB & 8.9010 & 10 & 3.22853 \\
NBC & 8.2340 & 10 & 1.78435 \\
Total & 8.4620 & 30 & 2.36264 \\
\hline
\end{tabular}

Non interest expenses to average assets

\begin{tabular}{llllll}
\hline & $\begin{array}{l}\text { Sum } \\
\text { Squares }\end{array}$ & of Df & $\begin{array}{l}\text { Mean } \\
\text { Square }\end{array}$ & F & Sig. \\
\hline Between Groups & 9.642 & 2 & 4.821 & 6.018 & .007 \\
Within Groups & 21.629 & 27 & .801 & & \\
Total & 31.271 & 29 & & & \\
\hline
\end{tabular}

Mean and standard deviation of non interest expenses to average assets

\begin{tabular}{llll}
\hline Banks & Mean & N & Standard deviation \\
\hline CRDB & 5.4890 & 10 & .83921 \\
NMB & 6.6300 & 10 & .69914 \\
NBC & 5.3740 & 10 & 1.10007 \\
Total & 5.8310 & 30 & 1.03842 \\
\hline
\end{tabular}

